O. Gulbs, Dr of Psychology, Prof., 1960.09.05m@gmail.com

ORCID ID 0000-0002-5300-8570,

A. Kobets, Dr of Psychology, Prof.,

Kobezalex59@ukr.net

ORCID ID 0000-0003-2185-4606

Pavlo Tychyna Uman State Pedagogical University, Uman, Ukraine

\title{
PSYCHOLOGICAL REHABILITATION OF PARTICIPANTS IN COMBAT ACTIONS
}

The article considers the issues of theoretical analysis of psychological rehabilitation of combatants in Ukraine and abroad. The aim of the study was a theoretical analysis of the psychological rehabilitation of participants in the war dialects of Ukrmo. During the study, we used theoretical methods, including analysis, synthesis, comparison. According to the Ministry of Veterans Affairs of Ukraine, servicemen must undergo free medical and psychological rehabilitation in appropriate centers. After all, servicemen are at increased risk of developing post-traumatic stress, according to scientists, one emotionally debilitating case may be enough to develop post-traumatic stress disorder, but combat often contributes to long-term and multiple effects of traumatic events. Psychological rehabilitation involves the provision of the following services: psychological diagnosis, psychological education and information, psychological counseling, psychological support and support, psychotherapy, group work, decompression. The main areas of psychological assistance to combatants include: determining the syndrome of socio-psychological maladaptation, psychological counseling, psycho-correctional work, the formation of self-regulation skills, socio-psychological training, defining life prospects, future plans and goals. Psychological rehabilitation of combatants in Ukraine is systemic and comprehensive. The experience of the United States and Israel shows the importance of constant monitoring and, if necessary, the need for psychogenic involvement of psychologists in working with the military. Following the example of the United States, psychologists have used cognitive-behavioral therapy, acceptance and attachment therapy (ACT), and interpersonal therapy (IPT) to reduce the negative effects.

Keywords: combatants; Post-traumatic stress disorder; psychological rehabilitation; directions of psychological assistance; world experience.

УдК 159: 378.011.32.037

DOI: https://doi.org/10.17721/1728-2217.2021.47.15-18

О. Гульбс, д-р психол. наук, проф. $19609050 @$ gmail.com ORCID ID 0000-0002-5300-8570, О. Кобець, д-р психол. наук, проф. Kobezalex59@ukr.net@gmail.com ORCID ID 0000-0002-9096-6313

Уманський державний педагогічний університет імені Павла Тичини, Умань, Україна

\section{РОЗВИТОК ЕМОЦІЙНОÏ КОМПЕТЕНТНОСТІ ВІЙСЬКОВОСЛУЖБОВЦІВ У ГРУПАХ АКТИВНОГО СОЦІАЛЬНО-ПСИХОЛОГІЧНОГО НАВЧАННЯ}

Розглянуто особливості розвитку емоційної компетентності військовослужбовців у групах активного соціальнопсихологічного навчання. Зазначено, що продуктивність роботи військовослужбовця при взаємодії з іншими також будується на ефективному сприйнятті, управлінні і контролі не лише власних емоцій, але й емоцій цих інших, і тому ефективна діяльність військовослужбовця безпосередньо залежить від його розвиненої емоційної компетентності. Емоційна компетентність як складова професійної компетентності є сукупністю емоційних і соціальних здібностей, здатності до розуміння власних емоцій та емоцій інших людей до управління емоційною сферою. Усі структурні компоненти емоційної компетентності взаємопов'язані, а їхня тісна взаємозалежність сприяє ефективній міжособистісній взаємодії. Зроблено припущення, що військовослужбовці з високим рівнем розвитку емоційної компетентності мають виражені здібності до розуміння власних емоцій та емоцій інших людей до управління емоційною сферою, яка обумовлює більш високу адаптивність та ефективність у спілкуванні. Активне соціально-психологічне навчання $є$ психолого-педагогічною формою розвитку емоційної компетентності і вдосконалення умінь і навичок взаємодії у суспільстві, здійснюваної в умовах групової навчально-тренувальної діяльності. Цей метод застосовано для формування в учасників специфічних емоційних, комунікативних, когнітивних та поведінкових умінь з метою підвищення емоційної компетентності, комунікативної та психологічної компетентності, емоційного інтелекту. Робота у групах активного соціально-психологічного навчання спрямована на позитивні зміни у розвитку емоційної компетентності їі учасників. Ефективність роботи у групах активного соціально-психологічного навчання з військовослужбовцями висока, оскільки віковий період ранньої та середньої дорослості припускає рухливість, пластичність і сензитивність емоційної та інтелектуальної сфер особистості. Отримані за результатами експерименту дані достовірно підтверджують ефективність застосування методу активного соціально-психологічного навчання у розвитку емоційної компетентності у військовослужбовців.

Ключові слова: емоційна компетентність; активне соціально-психологічне навчання; професійна компетентність; міжособистісна взаємодія; емоційний інтелект; військовослужбовці.

Постановка проблеми. Емоційні стани є показниками адаптованості військовослужбовця як особистості до поточних змін. Такими показниками $є$ позитивні емоції, які він відчуває у процесі взаємодії з оточуючими у професійній та побутовій сферах, задовільне самопочуття, відчуття душевного комфорту. У кожного військовослужбовця $є$ концептуальна модель зовнішнього світу, за якою формується план і програма поведінки. У військовослужбовців з високим рівнем тривожності ця модель нестійка, що в екстремальній ситуації може призводити до відмови від діяльності. Негативно впливають на адаптацію, зокрема, нездатність вчасно й адекватно оцінювати власний емоційний стан і керувати ним. Вплив подібних чинників може спричинити відповідні негативні емоційні реакції - роздратування, тривогу, страх, відчай тощо аж до стресового стану.
Успішне виконання професійних функцій військовослужбовцем безпосередньо залежить від його вмінь вибудовувати конструктивні міжособистісні стосунки з оточуючими. Йому важливо сформувати у собі готовність розуміти різних людей, уміння орієнтуватися у різних моделях їхньої життєдіяльності, вміння взаємодіяти з ними, бачити їхню неповторність та унікальність, приймати їхні переваги і недоліки. Продуктивність роботи військовослужбовця при взаємодії з іншими також будується на ефективному сприйнятті, управлінні і контролі не лише власних емоцій, але й емоцій цих інших. Тому ефективна діяльність військовослужбовця безпосередньо залежить від його розвиненої емоційної компетентності.

Аналіз останніх досліджень. Як зазначає сучасний дослідник емоційної компетеності О. Льошенко, на 
сучасному етапі розвитку суспільства проблема компетентності в розумінні та вираженні емоцій постає достатньо гостро, оскільки штучно насаджується культ раціонального ставлення до життя, для якого характерна заборона на емоції, що веде до їхнього витіснення із свідомості. Саме тому у сучасному суспільстві постійно зростає кількість людей, які страждають неврозом. Вирішенню проблеми емоційних та психосоматичних розладів могла б сприяти цілеспрямована робота з розвитку емоційної обізнаності, яка у сучасних дослідженнях називається емоційною компетентністю [6]. О. Лібіна, вивчаючи індивідуальні відмінності у реагуванні на стрес, вводить поняття емоційної компетентності, яку визначає як здатність особистості здійснювати оптимальну координацію між емоціями і цілеспрямованою поведінкою. Надалі вона розглядає поняття емоційної компетентності $з$ психотерапевтом, протиставляючи його захисній поведінці і при цьому залишаючи у тіні склад, структуру і властивості цього інтегрального утворення [5, с. 12-24]. Г. Юсупова розглядає емоційну компетентність як групу здібностей до саморегуляції і регуляції інтерперсональних відносин шляхом розуміння власних емоцій та емоцій оточуючих [10].

В українській психології проблему емоційної компетентності досліджують у різних аспектах, наприклад: І. Матійків досліджував розвиток емоційної компетентності майбутніх фахівців професій типу людина-людина; В. Зарицька і В. Борисенко вивчали її як детермінантну складову професійного становлення фахівців соціономічного напряму; Л. Любіна, М. Тимофрієва і В. Осипенко - як показник психологічного здоров'я особистості майбутніх лікарів; О. Лазуренко дослідив проблему визначення змісту емоційної компетентності; I. Матійків розробив тренінг емоційної компетентності; М. Корман вивчав розвиток емоційного інтелекту та емоційної компетентності як передумову запобігання професійного вигорання, а Ю. Гичко запропонувала програми формування емоційної компетентності майбутніх психологів засобами коуч-технологій [1-4; 7-9]. Але провідним методологом у сфері розробки, обґрунтування і практичної реалізації методу активного соціально-психологічного навчання була і залишається академік Т. Яценко, яка зазначає: "Мотив самопізнання - визначальний для формування психокорекційної групи активного соціально-психологічного навчання (АСПН) за умов практичної дії принципу добровільності. Водночас, враховуючи наявність особистісного опору, який виникає під час самопізнавальних дій, підтримання активності су6'єкта можливе лише у випадках розширення простору реалізації можливостей самопізнання та пізнання психіки іншого всіма учасниками дослідницько-орієнтованого типу навчання. Іншими словами, йдеться про актуалізацію важливих для психопізнавального процесу передумов рефлексії, розвитку сензитивності, емпатії та вміння узагальнювати все те, що сприймається, відчувається та емоційно переживається в групі" [11; 12, с. 165].

Мета статті - розкрити особливості розвитку емоційної компетентності військовослужбовців у групах активного соціально-психологічного навчання.

Виклад основного матеріалу дослідження. Емоційна компетентність як складова професійної компетентності, є сукупністю емоційних і соціальних здібностей, здатності до розуміння власних емоцій та емоцій інших людей до управління емоційною сферою. Усі структурні компоненти емоційної компетентності взаємопов'язані, а їхня тісна взаємозалежність сприяє ефективній міжособистісній взаємодії.

У складі емоційної компетентності виокремлено чотири базових компоненти з їхніми функціями: 1) саморегуляція (контроль імпульсів та управління емоці- ями, вираження емоцій, блокування негативних емоційних станів); 2) регуляція взаємин (соціальні навички, вміння будувати відносини з оточуючими); 3) рефлексія (самоусвідомлення, раціональне осмислення емоцій, виявлення власних мотивів); 4) емпатія (емоційно-когнітивна децентрація). Попарна комбінація цих компонентів утворює чотири функціональні блоки емоційної компетентності: 1) поведінковий блок (саморегуляція + регуляція відносин з іншими); 2) когнітивний блок (рефрлексія + емпатія); 3) інтраперсональний блок (саморегуляція + рефлексія); 4) інтерперсональний блок (регуляція відносин з іншими + емпатія).

Таким чином, конструкт емоційної компетентності складається із чотирьох базових компонентів - саморегуляції, регуляції взаємин, рефлексії та емпатії, які утворюють чотири функціональні блоки - поведінковий, когнітивний, інтраперсональний та інтерперсональний.

Можна припустити, що військовослужбовці з високим рівнем розвитку емоційної компетентності мають виражені здібності до розуміння власних емоцій та емоцій інших людей до управління емоційною сферою, що обумовлює більш високу адаптивність та ефективність у спілкуванні. Для перевірки висунутого припущення ми обрали метод активного соціально-психологічного навчання. АСПН є психолого-педагогічною формою розвитку емоційної компетентності і вдосконалення вмінь і навичок взаємодії у суспільстві, здійснюваної в умовах групової навчально-тренувальної діяльності. Цей метод було застосовано для фрормування в учасників специфічних емоційних, комунікативних, когнітивних та поведінкових умінь з метою підвищення емоційної компетентності, комунікативної та психологічної компетентності, емоційного інтелекту. Активне навчання спрямоване на самостійне оволодіння знаннями та вміннями використовувати досвід розвитку емоційної компетентності. Застосування методів АСПН дозволяє розвинути навички спілкування і взаємодії у малій групі, якою є військовий підрозділ, ссрормувати ціннісно-орієнтаційну єдність групи; навчити гнучкій зміні соціальних ролей залежно від ситуації, прийняттю моральних норм і правил спільної діяльності, розвинути навички аналізу і самоаналізу у процесі групової рефлексії. Із цією метою було розроблено корекційно-розвивальну програму "Розвиток емоційної компетентності військовослужбовців" у групах АСПН, яка мала вирішити такі завдання:

- виявлення рівня емоційного інтелекту членів групи;

- збагачення учасників групи знаннями про сутність емоційної компетентності, їі характеристики та ефективність міжособистісної взаємодії;

- навчання елементам емоційного інтелекту і розвиток навичок самоконтролю та емпатійних відносин у взаємодії з іншими;

- допомога в адекватному самооцінюванні, самоаналізу і саморефлексії;

- розвиток емоційної зрілості та чуттєвого сприйняття іншого:

- зняття негативних установок до інших;

- розвиток емоційної компетентності, загальної комунікативної толерантності, спостережливості та здібностей до емоційного інтелекту.

Важливу роль у розвитку емоційної компетентності має участь військовослужбовців у тренінгових заняттях, виконанні спеціальних вправ та психологічних ігор. Найбільший інтерес учасники виявили при виконанні таких вправ: "Емоційне слухання", "Усмішка", "Асоціації", "Свій стиль", "Відвертість", "Стійкість", "Емоції і злість", "Приємні спогади", "Скульптура", "Очі. Погляд", "Жести. Поза", "Настрій", "Візуалізація", "Подарунки", "Сімейний альбом". Згідно з програмою розвитку емоційної компетент- 
ності для них проводились такі тренінгові заняття: "Розвиток емоційного інтелекту", "Особистісне зростання", "Емоційна стійкість", "Позитивне самовиховання та впевнена поведінка". На тренінгових заняттях використовувались такі психологічні ігри: "Корабельна аварія", "Твоє обличчя", "Пошук скарбів", "Хто я?", "Два королівства", "Перестановка ролей".

Відповідно до корекційно-розвивальної програми у групах активного соціально-психологічного навчання підібрано комплекс методів для проведення занять, які відповідають поставленій меті. Згідно з програмою проводилась групова практична робота. Специфіка цієї програми полягає в тому, що вона спрямована на зміну поведінки, на розвиток емоційної компетентності, емоційного інтелекту, емоційно-вольових, когнітивних якостей особистості. В основі продуктивного, якісного проходження програми лежить співпраця, цілеспрямованість діяльності і щирість у вираженні своїх думок, а також активність військовослужбовця і його творче, дослідницьке ставлення до занять. Цей комплекс методів застосовувався зі зростанням рівня складності завдань. Ефективність застосованої програми мала б проявитись у підвищенні рівня емоційної компетентності учасників, для фріксації ключових показників передбачалось застосування психодіагностичних методик та об'єктивна реєстрація змін їхньої особистості.

У дослідженні взяли участь 56 осіб, які були поділені на контрольну та експериментальну групи. На першому етапі дослідження використовувались методики "Емоційний інтелект" Д. Люсіна і "Діагностика мотиваційних орієнтацій у міжособистісних комунікаціях" І. Ладанова та В. Уразаєвої. Було отримано такі результати: у 37,5 \% військовослужбовців було діагностовано середній рівень розвитку емоційної компетентності, у 13,75 \% - високий і у $48,75 \%$ - низький. На другому етапі після апробації авторської корекційно-розвивальної програми "Розвиток емоційної компетентності військовослужбовців" було проведено повторне вимірювання показників.

Результати дослідно-експериментального дослідження з розвитку емоційної компетентності у військовослужбовців дають підстави зробити такі висновки. Середньогруповий рівень розвитку емоційної компетентності в експериментальній і контрольній групах відповідає середньому значенню. Найменш розвиненим в обох групах виявилися показники - усвідомлення почуттів та емоцій своїх та інших людей, що належить до когнітивного блоку емоційного інтелекту. Найбільш розвиненим компонентом емоційної компетентності виявився показник управління власними почуттями та емоціями, що може пояснюватися проведенням тренінгових занять.

Для військовослужбовців обох груп (контрольної та експериментальної) характерна тенденція до яскравої виразності таких компонентів емпатійних здібностей, як "установки, що сприяють емпатії" та "ідентифрікація". Значення інтегрального показника емпатійних здібностей в експериментальній і контрольній групах виявились на низькому рівні. Головними перешкодами у встановленні емоційних контактів стали: неадекватність у прояві емоцій, невміння керувати емоціями і дозувати їх, а також перешкода - небажання зближуватися з людьми на емоційній основі. Результати свідчать про те, що у військовослужбовців емоції ускладнюють їхні взаємодії з іншими людьми.

На контрольному етапі у контрольній групі відбулися деякі незначні зміни:

- збільшилися значення показника "усвідомлення власних почуттів та емоцій" (з 4,2 до 4,3 бала), показника "усвідомлення почуттів і емоцій інших людей" (з 3,7 до 3,8 бала) та інтегративного показника емоційної компетентності (з 5,9 до 6,1 бала). Значення за показником "управління власними почуттями та емоціями" знизилося $з$ 7,8 до 7,7 бала. Показник "управління почуттями та емоціями інших людей" залишився незмінним (5,5 бала). У цілому спостерігаються незначні зміни;

- знизилися значення за усіма показниками емпатійних здібностей, окрім ідентифікації та установок, що сприяють емпатії;

- збільшилися значення показників невиразності емоцій, домінування негативних емоцій. Показник "небажання зближуватися з людьми на емоційній основі" залишився на тому ж рівні, при зниженні значень шкал "невміння керувати емоціями" і "неадекватність проявів емоцій";

- діагностика мотиваційних орієнтацій у міжособистісних комунікаціях за методикою І. Ладанова і В. Уразаєвої засвідчила, що військовослужбовці контрольної групи на середньому рівні продемонстрували орієнтацію на прийняття партнера у спілкуванні 21,3 бала (збільшення на 0,2 бала), показник "адекватність сприйняття і розуміння партнера по спілкуванню" змінився з 18,7 на 19,0 (збільшення на 0,3 бала). Показник "орієнтація на досягнення компромісу" становив 20,8 (зниження на 0,8 бала);

- діагностування військовослужбовців за методикою "Діагностика комунікативного контролю (М. Шнайдер)" засвідчило, що цей показник у контрольній групі становив 4,2 бала (динаміка 0,3 бала);

- за усіма компонентами емоційної компетентності в експериментальній і контрольній групах на контрольному етапі результати не змінилися. У цілому всі спостережувані зміни в експериментальній і контрольній групах статистично незначущі.

Водночас на контрольному етапі в експериментальній групі відбулися значні зміни, а саме:

- виявлено результати, які свідчать про покращення показників за усіма компонентами емоційного інтелекту. Значення інтегративного показника емоційного інтелекту також зросло, що було підтверджено статистичною обробкою. Статистично достовірними виявилися відмінності за всіма показниками, окрім показника "управління почуттями та емоціями інших людей";

- відбулися суттєві зміни за показниками емпатійних здібностей. Відбулася позитивна динаміка за всіма компонентами. Достовірність відмінностей підтвердилася на рівні значущості за $p=0,05$ і $p=0,01$. Окрім того, відбулось негативне зрушення в значеннях за всіма шкалами перешкод у встановленні емоційних контактів. Статистично достовірні відмінності між значеннями було виявлено за всіма показниками, окрім "домінування негативних емоцій";

- діагностика мотиваційних орієнтацій у міжособистісних комунікаціях за методикою І. Ладанова і В. Уразаєвої засвідчила, що військовослужбовці експериментальної групи на високому рівні продемонстрували орієнтацію на прийняття партнера у спілкуванні 26,4 бала (збільшення на 6,3 бала) та орієнтацію на досягнення компромісу 27,6 (динаміка на 5,3 бала), показник "адекватність сприйняття і розуміння партнера по спілкуванню" змінився з 19,8 на 25,7 (динаміка 5,9 бала). Загальний рівень гармонійності комунікативних орієнтацій також збільшився (з 28,6 на 65,1). Статистично ж достовірні відмінності між значеннями було виявлено за всіма показниками;

- результати за всіма компонентами емоційної компетентності змінилися. Зокрема, результати когнітивного компонента збільшилися на 2,9 бала, динаміка 3 особистісного компонента становить 2,4 бала. Поведінковий компонент також зазнав змін з 6,4 до 11,5 (динаміка - 5,1 бала). Загальний інтегральний показник емоційної компетентності змінився 3 14,1 на 23,0 бали 
(динаміка 8,9 бала). Достовірність відмінностей за всіма показниками підтвердилася.

Таким чином, отримані за результатами експерименту дані достовірно підтверджують ефективність застосування методу активного соціально-психологічного навчання (АСПН) у розвитку емоційної компетентності у військовослужбовців.

Висновки. Отже, емоційна компетентність розуміється як здатність усвідомлювати емоції, досягати і генерувати їх так, щоб сприяти розумінню емоцій і управляти ними, сприяючи своєму емоційному та інтелектуальному зростанню. Емоційна компетентність пов'язана зі здібностями, які означають: точність оцінки і вираження емоцій, як самого індивіда, так і людей, що оточують його; когнітивну асиміляцію емоційного досвіду; розпізнавання, розуміння та осмислення емоцій. Ефективність роботи у групах АСПН з військовослужбовцями висока, оскільки віковий період ранньої та середньої дорослості припускає рухливість, пластичність і сензитивність емоційної та інтелектуальної сфер особистості. Робота у групах АСПН спрямована на позитивні зміни в розвитку емоційної компетентності її учасників. Розвинена емоційна компетентність військовослужбовців $€$ важливою умовою їхнього професійного успіху, задоволеності та впевненості у професійній діяльності. Між тим існує потреба у подальшому дослідженні феномену емоційної компетентності, її структури, шляхів ії розвитку, що відкриє реальну можливість оптимізації взаємовідносин через глибше усвідомлення емоційних станів, які виникають у професійній діяльності військовослужбовців.

Список використаної літератури

1. Гичко Ю.В. Щодо результатів апробації авторської програми формування емоційної компетентності майбутніх психологів засобами коучтехнологій // Knowledge, Education, Law, Management. 2020. №8(36) с. 103-109.

2. Зарицька В.В., Борисенко В.М. Емоційна компетентність як детермінантна складова професійного становлення фахівців соціономічного напряму // Молодий вчений. , 2017. № 4(44). С. 241-245.

3. Корман М.М. Розвиток емоційного інтелекту та емоційної компетентності як передумова запобігання професійного вигорання // Вісн. Нац. ун-ту оборони України, 2012. № 4(29). С. 175-178.

4. Лазуренко О.О. До проблеми визначення змісту емоційної компетентності // Молодь і ринок, 2014. № 2(109). С. 124-129.

5. Либина Е В., Либин А.В. Стили реагирования на стресс // Стиль человека: психологический анализ. Москва : Смысл, 1998. 204 с.

6. Льошенко О. Емоційний інтелект та емоційна компетентність: проблеми співвідношення // Вісн. Київ. нац. ун-ту імені Тараса Шевченка "Психологія. Педагогіка. Соціальна робота", 2010. № 2. С. 49-52.

7. Любіна Л.А., Тимофієва М.Ф., Осипенко В.А. Емоційна компетентність як показник психологічного здоров'я особистості майбутніх лікарів // Психологічний часопис, 2018. № 5(15). С. 81-97.
8. Матійків І.М. Розвиток емоційної компетентності майбутніх фахівців професій типу "людина - людина": психологічний аспект // Проблеми та перспективи розвитку економіки і підприємництва та комп'ютерних технологій в Україні : зб. тез за мат-ми VIII наук.-техн. конф. наук.-пед. працівників, 26-31 березня 2012 року / Нац. ун-т "Львівська політехніка", І технологій. Львів, 2012. С. 240-243.

9. Матійків І.М. Тренінг емоційної компетентності : навч.-метод. посібник. Київ : Педагогічна думка, 2012. 112 с.

10. Юсупова Г.В. Состав и измерение эмоциональной компетентности : дис. ... канд. психол. наук. Казань, 2006. 208 с.

11. Яценко Т.С. Теорія і практика групової психокорекції: Активне соціально-психологічне навчання : навч. посібник. Київ: Вища шк. 2004.697 с

12. Яценко Т.С. Метод активного соціально-психологічного навчання: індуктивно-дедуктивне обґрунтування // Психологія і суспільство, 2001. №1. С. 164-173.

\section{References}

1. Gychko Ju.V. (2020) Regarding the results of approbation of the author's program of formation of emotional competence of future psychologists by means of coach-technologies. Knowledge, Edusation, Law, Management. №8(36). Pp. 103-109. [in Ukranian]

2. Zarytska V.V., Borysenko V.M. (2017) Emotional competence as a deterministic component of the professional development of socialist professionals. A young scientist. № 4(44). Pp. 241-245. [in Ukranian]

3. Korman M.M. (2012) Development of emotional intelligence and emotional competence as a prerequisite for prevention of professional burnout. Deputy of the National University of Defense of Ukraine. № 4(29). Pp. 175-178. [in Ukranian]

4. Lazurenko O.O. (2014) To the problem of defining the content of emotional competence. Youth and the market. № 2(109). Pp. 124-129. [in Ukranian]

5. Libina E.V., Libin A.V. (1998). Styles of response to stress // Human style: psychological analysis. Moskow: Smysl, 204 pp. [in Russian]

6. Loshenko O. (2010) Emotional Intelligence and Emotional Competence: Correlation Problems. Bulletin of Taras Shevchenko National University of Kyiv "Psychology. Pedagogy. Social work". № 2. Pp. 49-52. [in Ukranian

7. Liubina L.A., Tymofiieva M.F., Osypenko V.A. (2018) Emotional competence as an indicator of the psychological health of the personality of future doctors. Psychological magazine. № 5(15). Pp. 81-97. [in Ukranian]

. Matiikiv IM (2012) Development of emotional competence of future specialists of professions such as "man - man": psychological aspect. Problems and prospects of development of economy and business and computer technologies in Ukraine: a collection of abstracts on the materials of the VIII scientific and technical competition. March 26-31. Lviv. Pp. 240243. [in Ukranian]

9. Matiikiv I.M. (2012) Emotional competence training: educational and methodical manual. Kyiv: Pedagogical thought. 112 pp. [in Ukranian]

10. Yusupova G.V. (2006). Composition and measurement of emotional competence: the dissertation of the candidate of psychological sciences. Kazan. 208 pp. [in Russian]

11. Yatsenko T.S. (2004) Theory and practice of group psychocorrection: Active socio-psychological training: Tutorial. Kyiv: High school. 697 pp. [in Ukranian]

12. Yatsenko T.S. (2001) Method of active social and psychological learning: inductive-deductive substantiation. Psychology and society. №1. Pp. 164-173. [in Ukranian]

Надійшла до редколегії 11.08.21

O. Gulbs, Dr of Psychology, Prof.,

1960.09.05m@gmail.com

ORCID ID 0000-0002-5300-8570,

A. Kobets, Dr of Psychology, Prof.,

Kobezalex59@ukr.net

ORCID ID 0000-0003-2185-4606

Pavlo Tychyna Uman State Pedagogical University, Uman, Ukraine

\section{DEVELOPMENT OF SERVISEMAN IS EMOTIONAL COMPETENCE IN ACTIVE SOCIAL-PSYCHOLOGICAL TRAINING GROUPS}

The article is devoted to the disclosure of the peculiarities of the development of emotional competence of servicemen in groups of active social and psychological training. It is noted that the productivity of a serviceman in interaction with others is also based on the effective perception, management and control not only of their own emotions, but also the emotions of others. Therefore, the effective activity of a serviceman directly depends on his developed emotional competence. Emotional competence, as a component of professional competence, is a set of emotional and social abilities, the ability to understand their own emotions and the emotions of others, to manage the emotional sphere. All structural components of emotional competence are interconnected, and their close interdependence promotes effective interpersonal interaction. It is assumed that servicemen with a high level of emotional competence have a strong ability to understand their own emotions and the emotions of others, to manage the emotional sphere, which leads to greater adaptability and efficiency in communication. Active socio-psychological training is psychologicalpedagogical form of development of emotional competence and improvement of abilities and skills of interaction in a society carried out in the conditions of group educational and training activity. This method was used to form in participants specific emotional, communicative, cognitive and behavioral skills, in order to increase emotional competence, communicative and psychological competence, emotional intelligence. Work in groups of active socio-psychological training is aimed at positive changes in the development of emotional competence of its participants. The effectiveness of work in groups of active socio-psychological training with servicemen is high, as the age period of early and middle adulthood involves mobility, plasticity and sensitivity of the emotional and intellectual spheres of personality. The data obtained from the results of the experiment reliably confirm the effectiveness of the method of active socio-psychological training in the development of emotional competence in servicemen.

Keywords: emotional competence; active socio-psychological training; professional competence; interpersonal interaction; emotional intelligence; military. 